\title{
Impact of Modarabah Dealer by Effort Value Accounting on Islamic Bank Financial Statements
}

\author{
Abdullah Ibrahim Nazal ${ }^{1} \&$ Fuad Al-Fasfus ${ }^{2}$ \\ ${ }^{1}$ Islamic Banking Department, Zarqa University, Jordan \\ ${ }^{2}$ Accounting Departments, Zarqa University, Jordan \\ Correspondence: Abdullah Ibrahim Nazal, Islamic Banking Department, Zarqa University, Jordan. Tel: \\ 962-788-837-709. E- mail: nazzalacademy@yahoo.com
}

Received: October 2, 2017

Accepted: October 29, 2017

Online Published: November 20, 2017

doi:10.5539/ijef.v9n12p229

URL: https://doi.org/10.5539/ijef.v9n12p229

\begin{abstract}
Modarabah is partnership contract. Its strength points and weakness points impact Islamic banks results. This study tries to find way to measure Modarabah human effort in financial statements based on analysis the original Modarabah contract accounting. Practically, Modarabah trader is the dealer by effort. Some Islamic bank cancel way of giving cash to partner in order to work as Modarabah trader because of risk but Islamic bank applies the way to get the cash from customer and work by his employee effort as Modarabah trader. Modarabah trader is the dealer by effort has impact assets, liabilities, equities, cost and return. This proves the impact of Modarabah on financial statement adjusted and estimated.
\end{abstract}

Keywords: human accounting, disclosures, financial statements, trust, Islamic bank

\section{Introduction}

Some people or companies have savings in Islamic banks on other hand they may have capital to share in invest but they do not have the suitable experiences or time to make their personal investment. Islamic bank gives Modarabah sharing service to solve this problem and give suitable profit. Jordan Islamic bank uses this capital as a dealer by effort. Its responsibility is limited by managing the capital in the markets to make profit. When there is lose Islamic bank will just lose his employees efforts because there will not be in compensations as salary or insurance but when there is profit Islamic bank will get part of this profit. Jordan Islamic bank managing Modarabah risk by: "Facing Investment Risk Box". The returns of this box comes from sharing investing profit before it be gotten in reserves or distributed between the customers and the bank. This box has law (Jordan Islamic bank annual report, 2005).

Islamic banks does not deal with credit interest but Islamic banks deal with selling goods services, sharing services, work services, and lease services. It has types and risks. Every Islamic bank chooses the suitable type of those services and shows it in its balance sheet. It has to apply the services Islamic rule based on its Supervisory Sharea'ha Board. (Youssef Kamal, 1986) said price of service must be fixed in contract after sign and must not be change up to time or default or it may cause forbidden Reba.

Modarabah has types. Customer can be the dealer by effort in Modarabah as trader. Modarabah can be limited by time condition, reducing risk condition, and type of managing capital by contracts as type of selling, type of leasing, type of sharing, and type of work (Fatawa, 1994). When dealer by effort causes profit his effort will get the value in financial statements and when dealer by effort causes lose his effort will lose the value in financial statements. Success of estimated dealer by effort success needs disclosure to find the current value.

\subsection{Introduce the Problem}

Modarabah service faced problem in Jordan Islam Bank when it gives cash to trader to invest this cash in market. After establishing business in this bank in1978 there was equal $80 \%$ of this service gotten in lost. The bank consider this service is bad service and cancel it from the assets on other hand almost of Jordan Islamic bank investing work depend on Modarabah by consider the bank as the trader that get the cash to work in market. Dealer by effort in Modarabah impact assets, liabilities, equities, cost and return. It needs to be measured based on human resources accounting. The problem comes as result to find human effort accounting impact on Islamic bank financial statements based on sharing by effort in Modarabah service and tries to cover the gap which was 
explained by (Philip \& Barry, 1976): there is gap between accounting methods that being developed to reflect social aims in financial terms but it has problem practically to understand social benefit or non financial cost. Human resource satisfaction is now the standard therefore supporter of Islamic bank will studying reasons of changing mangers, employees, and workers to find Islamic bank problems. The problem questions are as follow:

1) Can we get the human effort accounting based on studding original Islamic Modarabah contract accounting?

2) Can we get human efforts accounting in Islamic bank financial statements based on the original Islamic Modarabah contract types?

\subsection{Explore Importance of the Problem}

The Islamic bank services including Modarabah contract. Its strength points and weakness point must be shown in the Islamic bank financial statements. It impacts Islamic bank financial statements adjusted and estimated. This search add to theoretically studies this impact and helps leaders to control Modarabah risk practically. It shows impact on assets, liabilities, equities, cost and return also show impact of Modarabah ways changing or dealer by effort changing.

\subsection{The Objectives}

This search aims to find the follow:

1) To get the human effort accounting based on studding original Islamic Modarabah contract accounting?

2) To get human resources efforts accounting in Islamic bank financial statements based on the original Islamic Modarabah contract types?

\subsection{Describe Relevant Scholarship}

There is rarely studding of Modarabah impact on financial statements adjusted and estimated. Almost studies were search the Modarabah by customer as trader but they did not discuss Modarabah by Islamic bank employee also there were studies concentrated on Islamic bank evaluation. It compares between Islamic bank and Traditional bank to show weakness points as: (Shawki, 2011) found by empirical study weakness of operational efficiency in Islamic banks. It explained weakness of using resources and mix of resources than traditional bank. Weakness increase cost. (Elsayed, 2013) found differences between Islamic banks and Traditional banks before, during and after the financial crises in 2008 by financial ratios as: liquidity, credit, risks, profitability and solvency which made impact of crises in different affection between Traditional bank and Islamic bank. (Frederick, 2011) evaluated Islamic banking after it works in the west. He found Islamic bank weakness after work in west because of traditional bank competition but crises will success expansion Islamic bank industry as way to managing risk.

On other hand, there were studies concentrate on Modarabah. Studies were concentrated on Modarabah ignorance risk as: (Hassan, 1998) explained the problem of different ways of calculating Modarabah accounting data and it is not clear. Some Islamic banks who deal as dealer by effort merging cost of managing Modarabah by the employee with Modarabah cost but other bank do not account the employee cost from Modarabah cost. The ignorance needs rules to measure Modarabah fairly.

(Abdullah, 2006) searched the Modarabah service in Jordanian Islamic banks. he found by questioner that Modarabah was not give high return in managers opinion based on its high risk therefore it was reduced in the bank assets. (Musaed, 2002) searched finance Islamic bank services as Modarabah in Sudan and found its impact factors as misunderstand the condition, timing, type of dealer by effort customers, Insurance, change of environment which increase its risk. (Mansur \& Nabeel, 2010) explained the disclosure of Modarabah contract condition it must show the profit distributed and the accepted cost to understand way of calculated.

\section{Importance and Measured of Human Resources Accounting}

Managers, workers and employees are called human resources. They are responsible to understand their work divisions to reach Islamic bank aims practically. Their work with experience, ethical, reputation, training, studying field, cost, return, authorized, and insurance have values to classify every manager, employee, and worker. Human resource satisfaction will give the bank their loyalty and do their best effort to reduce cost and increase profit. (Banner \& Baker, 1973, p. 47) said:" Employee satisfaction and growth is a legitimate corporate goal by it self, regardless of whether or not it contributes to profit". Human resources are wealth and it must be showed in financial statements to help in evaluation. (Woodruff, 1970) explained that employee is investment as assets therefore he has expenses to give profit as any asset

Human resources are important because it adds value to Islamic bank. Its cost less than its return therefore 
Islamic bank get profit. It gives data accounting of expenses for every service practically depends on employee accounting data. Employee and workers is direct dealer with the customer, service procedures, service steps, service quality, service cost, service developed, service success, and service default. They can give strength points and weakness points. Manager, employee, worker have different value. Some of them can reduce cost, increase sales, and develop services based on customer needs and make reputation. There value can reflect on financial statements successfully.

Value of Islamic bank human resources appear clearly when Islamic bank needs them in suitable time with suitable place. This value is increased when Islamic bank lose some of his experts.

Human resources give disclosure information in financial statements (Fariborz et al., 2011). By directing work, they understand problems, real costs and expect profit. Any changes of employees means misunderstand financial.

Many searchers try to find way of measure human resources: They agree that human resources have value in company but they have different in the way of measures this value. Some of them consider the value as non financial impact other considers it as add value to company because of their reputation on other hand some searchers evaluate human resources based on profitability of their working result. Finally, some searchers measure human resource based on employees satisfied because satisfied will direct employee to protect the company and contact with customers to keep company profitability. (Thomas, 2016) explained that human resources measured comes as result to the global transition from manufacturing to service which need human resource knowledge and skills also leaving of employee will cause problem. He suggest model to evaluate human resources in financial return and cost based on employee value in currently time and in future.

(Maria \& Kel, 2010) studied human resources account to make international development by reach a suitable measurement for human capital. They explained that the strong growth of international financial reporting standards is affected by ways of human resources accounting. (Suresh, 2011) studied human resources accounting model in Indian industries. He found that human resources must be evaluated as wealth and related to the financial statement of organization in order to make user of financial statement able to communicate human resources wealth from time to time. (Fariborz et al., 2011) studied evaluation methods of human resource accounting as factors impact historical cost, replacement cost, different opportunities cost, estimated future cost and estimated future advantage also found its affect on managing decision evaluation. (Odigwe \& Eluwa, 2014) found the importance to value the human force and this value must impact the financial statements as intangible assets based on the human resource economic value. (Philip \& Barry, 1976) concentrated on cost and benefit of human resource development programs to get the financial benefit. This benefit or cost is related to non financial impact. (Brian, Thomas, \& Matthew, 2014) found that human resources are capital because it adds value to organization and this value of human resource should be shown in the financial report.

These searchers opinion give idea about difficult of choosing the measure.

\section{Suggestion of Human Effort Accounting Based on Studding Original Islamic Modarabah Contract Accounting}

In this study searchers will try to apply measure depends on weakness points and strength points of human resources in the company based on employee work success. This idea can be examined by the follow ratios:

1) Cause asset growth: human resource can buy goods in low price and when it stores goods in Islamic bank stores it become high price as result to increasing market price.

2) Cause new asst: human resources develop new service to be produced as new assets.

3) Reduce liabilities as restructure credits of delay buying cost to sellers by get agreement to reduce credit as goods discount. This comes as result to negotiation skills.

4) Increase equities: human resource buy Islamic bank new shares to increase assets.

5) Reduce cost: by does the work with short time and less cost than other human resources in other bank.

6) Increase sales: human resource can increase promotion of services to their families, friends locally and internationally.

7) Sharing in solving Islamic bank problems in branches and Islamic sharing in companies: they can give information up date to discover new problem also they can share in solving problem because of their experiences.

8) Give reputation: some managers or employees have stories of successful and when they work in the bank they 
will give their reputation to the Islamic bank as promotion.

9) Support Islamic bank in default case: human resource buy Islamic bank new shares to buy liabilities before the bank buy compensation as delay of buying liability or to avoid get in Islamic bank clear.

10) Develop tools: some human resources are inventors and have skill to improve tools or develop new tools to growth assets and solve problems.

\subsection{Original Islamic Modarabah Contract Accounting}

Modarabah is service in some Islamic banks. Islamic bank can be the dealer in Modarabah with effort depends on his human resource experiences as working in project with customer's capital. Islamic bank can use his capital in Modarabah and the other dealer by effort will be the customer. Dealer by effort and dealer by capital are sharing in Modarabah based on Islamic rules as follow: (Jordan Islamic Bank Fatawa Sharea'ha, 1994).

1) One dealer will give capital and other dealer will work with capital depend on his experience.

2) Profit will be distributed based on the dealers accept percent as $50 \%$ to every dealer or $20 \%$ for dealer and other will get $80 \%$. This depends on the service contract agreement acceptance.

3) Lose of capital will just affect on the sharer of capital but sharer with effort will just lose his time and effort.

4) Sharer by capital can get grantee from sharer by effort to get his right just when sharer by effort makes Islamic mistakes or law mistakes.

5) Capital must be given to the dealer by effort to make business and the owner of capital must not order the other dealer work as employee because he has the honest and experience to do his best to success Modarabah service.

This condition shows the Islamic rules to accept partner human effort accounting cost and return in Modarabah. These will rule the measure of Modarabah result and documentary.

\subsection{Modarabah Human Effort Impact on Financial Statements}

These Islamic rules are the major conditions. Islamic bank can add other conditions based on the contract type. Modarabah contract is improved to meet Islamic bank needs. Its account shows value of human effort on increasing assets, increasing equity, decreasing liabilities, and increasing net profit. Different Modarabah service types will give different accounting of human effort accounting, see (Table 1):

Table 1. Impact of Modarabah contract types of human efforts accounting results

\begin{tabular}{|c|c|c|}
\hline Type of Modarabah & Its conditions & Its Accounting result \\
\hline Temporary Modarabah & $\begin{array}{l}\text { Add condition to limit sharing with time, as the } \\
\text { Modarabah contract for three years. }\end{array}$ & $\begin{array}{l}\text { Modarabah service will be end after the time and } \\
\text { bank get lose or profit as any project. When it is } \\
\text { ended it will be canceled from asset. }\end{array}$ \\
\hline Permanent Modarabah & $\begin{array}{l}\text { Add condition to make Modarabah permanent } \\
\text { with out time }\end{array}$ & $\begin{array}{l}\text { Modarabah service is not end by time. It has two } \\
\text { ways which are: to be Permanent Modarabah asset } \\
\text { in Islamic bank assets or to consider sharing as } \\
\text { equities because Islamic bank will evaluate effort } \\
\text { as shares in the equities. }\end{array}$ \\
\hline $\begin{array}{l}\text { Unlimited effort condition } \\
\text { and it could be Temporary } \\
\text { Modarabah or Permanent } \\
\text { Modarabah }\end{array}$ & $\begin{array}{l}\text { There is no limit condition to direct or limit } \\
\text { Modarabah dealer with effort }\end{array}$ & $\begin{array}{l}\text { Modarabah service effort is being directed by time, } \\
\text { field of work, type of business, and type of } \\
\text { customers. In this case the effort accounting will } \\
\text { be with low risk. }\end{array}$ \\
\hline $\begin{array}{l}\text { Limited effort condition } \\
\text { Modarabah and it could be } \\
\text { Temporary Modarabah or } \\
\text { Permanent Modarabah }\end{array}$ & $\begin{array}{l}\text { There is limit condition to direct or limit } \\
\text { Modarabah dealer with effort. As way to } \\
\text { manage risk but not as way applying his work } \\
\text { to be employee. Ex: to work locally with } \\
\text { industry companies }\end{array}$ & $\begin{array}{l}\text { Modarabah service effort has to do with out limit } \\
\text { except the acceptance of Islamic rules and law. In } \\
\text { this case the effort accounting will be with high } \\
\text { risk. }\end{array}$ \\
\hline
\end{tabular}

Resources: done by researchers.

Modarabah is developed and need disclosure to understand effort accounting. This table shows the effort accounting as asset or equities in the Islamic bank. The effort accounting can explain human resource value in asset and equities. When Islamic bank needs credit services from other Modarabah company as buying goods by 
delay price, the Islamic bank liabilities will be increased but when the Islamic bank is the worker by effort in Modarabah the account effort will be in asset as selling goods. This means that Modarabah dealer by effort accounting can explain impact of human resources accounting depend on effort value. Value of employees, Manager and worker increased by their experiences and possibility to do work with small cost than others beside have the ability to reduce sales costs, operation costs, and managing risk to reduce loss or avoid it. Some of them are inventors. See (Table 2):

Table 2. Impact of Modarabah dealer by effort accounting in Islamic banks

\begin{tabular}{|c|c|}
\hline Human resources accounting way & Impact \\
\hline $\begin{array}{l}\text { 1- Human resources account as liabilities: as result to use } \\
\text { external employees or workers from out of the Islamic bank. } \\
\text { as buying goods from other Modarabah company by delay } \\
\text { price. }\end{array}$ & $\begin{array}{l}\text { It increases expenses based on human experiences and time of need } \\
\text { also this way of using human resource will transfer secrets out of } \\
\text { Islamic Banks beside increases expenses of time to understand Islamic } \\
\text { bank objectives. }\end{array}$ \\
\hline $\begin{array}{l}\text { 2- Human resources account in Modarabah as assets: Their } \\
\text { contracts with Islamic bank are as asset based on the contract } \\
\text { value. Human is investment as assets therefore he has } \\
\text { expenses to give profit as any asset (woodruff, 1970). }\end{array}$ & Increasing his value will increase Islamic bank return \\
\hline $\begin{array}{l}\text { 3- Human resources in Modarabah are equity: they own } \\
\text { Islamic bank shares as result to get shares up to their effort in } \\
\text { Islamic bank. }\end{array}$ & $\begin{array}{l}\text { They are increasing effort than other employees to increase there } \\
\text { distributed profit or assets growth and shares market price also they } \\
\text { share in Islamic bank loss case by loose effort expenses. Increasing his } \\
\text { value will increase reputation and support Islamic bank. }\end{array}$ \\
\hline 4- Human resources in Modarabah will & $\begin{array}{l}\text { Modarabah company does not give any dealer by salary and insurance } \\
\text { as expenses. The accept expenses is related to work needs }\end{array}$ \\
\hline $\begin{array}{l}\text { 5- Human resources in Modarabah are giving social } \\
\text { accounting when they supply government policy and supply } \\
\text { market controlling also it causes corporate between who own } \\
\text { experience with out capital and who own capital and can not }\end{array}$ & $\begin{array}{l}\text { Success of human resource means to give suitable product to cover } \\
\text { citizen needs locally which reduce government general budget deficit } \\
\text { as result to reduce import also loyalty to country will direct human } \\
\text { resources to be controller to protect economic and social needs. }\end{array}$ \\
\hline
\end{tabular}

Resources: done by researchers.

As result to Islamic bank human resource accounting the income statement and balance sheet becomes as in the (Table 3):

Table 3. Impact of Modarabah dealer by effort on balance sheet and income statement

\begin{tabular}{ll}
\hline human resource accounting in balance sheet & human resource accounting in income statement \\
\hline $\begin{array}{l}\text { Asset: by added human resource contracts as sharing effort with Islamic bank } \\
\text { capital by Modarabah Sharing contract as owning company or produce }\end{array}$ & \\
$\begin{array}{l}\text { Modarabah sharing service in assets for limit term } \\
\text { - (Liabilities): by rent human resource from out side Islamic bank }\end{array}$ & $\begin{array}{l}\text { No human resource work expenses as insurance or } \\
\text { salary }\end{array}$ \\
= Equities: by give human resource shares instead of cash or deal with human \\
resource as in Modarabah Sharing contract as dealer by effort without limit time
\end{tabular}
Resources: done by researchers.

These tables show risks of employee changing on Islamic bank competition and costs. When there is linking between every employee and cash flow of his operation contract there will be understand of the employee importance therefore human resource managing organizes tables to show name of employ, training courses, experience years, his study field, his job currently and in the past also tables show his targets to be done, his authorized, his customers, his leaders, his workers, his cost, his expect return, and his expect planning in future.

By loosing trust now days, some companies increase its insurance costs to avoid employee's immoral behavior risk or it gets suitable grantee from employee to grantee his work with out trickery or harming.

The problem of losing Modarabah capital by trickery comes as result to use human resource with out experiences to apply criminal orders and to keep secrets beside monopolizes information. In this case loss comes as result to have trickery experiences by direct jobs. Bad leaders can impact policy of accounting to reduce standards 
affection therefore some companies get in loss in spite of auditing.

Financial development causes economic development by promoting investment and making allocation of resources more efficient (Pedro \& Erwan, 2010) but in trickery environment developing Modarabah becomes tool to increase trickery.

\section{Conclusions}

Searchers found many results based on this search as follow:

First: Searchers found human effort accounting based on original Modarabah contract accounting by analysis the contract as result to the following:

- Islamic Modarabah original contract has risky way when the bank give cash to partner to work depend on his efforts with out sharing bank in managing but it reduce risk when the bank becomes the partner by his employee effort.

- Modarabah contract shows the human effort accounting because it show partner by effort strength and weakness impact Islamic Bank results.

Second: Searcher found human resources efforts accounting in Islamic bank financial statements based on the original Islamic Modarabah contract types as follow:

- Partner by effort in Modarabah impact assets, liabilities, equities, cost and return therefore Human resources efforts can be accounting in Islamic bank financial statements.

- Modarabah dealer by effort result is measure impact balance sheet and Income statement.

- Risky of Modarabah is depend on reputation, experiences, training, honest of dealer by effort whither dealer by effort is the customer or the Islamic bank.

Third: the last results prove the impact of Modarabah dealer by effort on financial statement adjusted.

\section{Recommendation}

Because of these results, Islamic bank has to show the Modarabah dealer effort impact on financial statement adjusted. This obligates to show financial statements and Modarabah dealer's strength point and weakness point to estimate future result.

\section{References}

Abdullah, N. (2006). Impact of Islamic rules on developing Islamic services in Jordanian Islamic bankstheoretically and practically study. Arab Academy of Finance and Banking Sciences, PhD thesis, Amman, Jordan, p. 119.

Banner, \& Baker. (1973). Human Resource Accounting: A Critical View. MSU Business Topics, 47.

Brian, S., Thomas, Z., \& Matthew, M. (2014). Human asset accounting and measurement: Moving forward. Journal of Business and Economics Research, 12(2), 93. https://doi.org/10.19030/jber.v12i2.8522

Elsayed, E. (2013). Comparative analysis of Qatar Islamic banks performance versus conventional banks before, during and after the financial crisis. International Journal of Business and Commerce, 3(3), 11. Retrieved from http://www.ijbcnet.com

Fariborz, A., \& Raiashekar, H. (2011). Decision- Making Based on Human Resource Accounting Information and Its Evaluation Method. Asian Journal of Finance \& Accounting, 3(1), 1-4, 10.

Frederick, V. P., \& Scheherazade, S. R. (2011). Globalization of Islamic Finance: Myth or Reality? International Journal of Humanities and Social Science, 1(19), 117. Retrieved from http://www.ijhssnet.com/journals/Vol_1_No_19_December_2011/12.pdf

Hassam Al-Ameen. (1998). Legal Modarabah and its modern application, Islamic research and training institute. Islamic Development Bank, Search no:11, p. 62. Retrieved from https://esytrunojoyo.files.wordpress.com/2016/01/al-mudharabah-syariyah.pdf

Jordan Islamic Bank annual report. (2005). The annual report no: 27 (p. 76). Amman, Jordan: Al sharq printing press.

Jordan Islamic Bank Fatawa sharea'ha. (1994). Announcement no (6), part (2), p. 26, 44. Al Sharq printing press, Amman, Jordan.

Mansur, M., \& Nabeel, Al-M. (2010). Accounting of Modarabah company in Islamic Jurisprudence- 
Comparative analytical study with contemporary Islamic banks. Jordanian Journal of Islamic Studies, 6(3), 73. Retrieved from http://repository.aabu.edu.jo/jspui/bitstream/123456789/236/1/624.pdf

Maria, B., \& Kel-Ann. (2010). Human Resource Accounting and International Developments: Implications for Measurement of Human Capital. Journal of International Business and Cultural Studies, 3, 1, 5, 13.

Musaed, A. (2002). Islamic banking finance risk- Sudan experiences. Conference of asset management and finance risk in Islamic and traditional banking work, united of Arabian banks, Beirut, Lebanon, p. 298.

Odigwe, F., \& Eluwa, I. (2014). Impact of human resource accounting on Bursary staff effectiveness: Implication for measurement and evaluation of human capital in Federal University, Nigeria. Public and Administration Research, 4(6), 43.

Pedro, S. A., \& Erwan, Q. (2010). Limited Enforcement, Financial Intermediation, and Economic development: A Quantitative Assessment. International Economic Review, 51(3), 804.

Philip, H. M., \& Barry, A. M. (1976). Accounting for the Costs and Benefits of Human Resource Development Programs: An Interdisciplinary Approach. Accounting Organizations and Society, 1(2\&3), 179-182. https://doi.org/10.1016/0361-3682(76)90022-2

Shawki, bu R. (2011). Operational Efficiency of Islamic Banks: A Comparative empirical study. Ph.D thesis, University of Farhat Abbas- Setif, Facility of economic and commercial services and management Sciences, Algeria, p287.

Suresh, M. (2011). Human Resource Accounting Model in Indian Industries. The Journal of Commerce, 4(2), 48-52.

Thomas, A. (2016). Human resources accounting: Suggested model for measurement and valuation. Finanse, Rynki Finansowe, Ubezpieczenia nr, 79(1), 173.

Woodruff, R. (1970). Human Resource Accounting, Chadians Chartered Accountant (pp. 2-7). Work in US department of health, education, welfare: report of special task force to the secretary, Washington, D.C., United States Government printing office, 1973.

Youssef, K. (1986). Zakat and rationalization of contemporary insurance (p. 153). Dar Al Wafa Publisher, Egypt.

\section{Copyrights}

Copyright for this article is retained by the author(s), with first publication rights granted to the journal.

This is an open-access article distributed under the terms and conditions of the Creative Commons Attribution license (http://creativecommons.org/licenses/by/4.0/). 